\title{
Scenario of Solid Waste Management in Jalandhar City
}

\author{
Manpreet Singh Saini, Ravi Inder Singh, and Sawan Singh
}

\begin{abstract}
Punjab is undergoing large hue and cry pertaining to solid waste collection, management and disposal the adhoc piece meal approach being followed by the bureaucrat is highly motivated via political will and in turn leading to chaotic situation that is going to be irreversible and may never be corrected in near future. The current scenario states that waste needs to be treated holistically, recognizing its source and its health impacts on general public. India, the fastest growing economy in the world is undergoing a massive stage shift from rural areas to urban clusters.

\begin{tabular}{|c|c|c|c|c|}
\hline W & A & S & T & E \\
\hline WISE & APPROACH to & SUSTAINABILITY & THROUGH & EXCELLENCE \\
\hline
\end{tabular}
\end{abstract}

Punjab is on the brink of a massive waste disposal crisis, but solutions are not forthcoming. The problem of waste is generally categorized in accordance with the capacity of cleaning and disposing of waste. New consumption patterns and social linkages are emerging. Most local governments and urban agencies have identified solid waste as a major problem that has reached proportions requiring drastic measures. Municipal solid waste consists of household waste, construction and demolition debris, sanitation residue and waste from streets. Major proportion of garbage is generated mainly from residential and commercial complexes.

Jalandhar is located in the center of Punjab on N.H 1.There are total 25,738 commercial establishments according to "Master Plan 2011".An individual survey carried out by The Tribune news paper reveals that only 530 commercial establishments avail the facility out of 56,000-60,000.

Total area of Jalandhar is $3401 \mathrm{kmsq}$ (M.C Jalandhar). There are approx 2.13 lakh houses (M.C Jalandhar) in Jalandhar but average 1.50 lakh urban households avail the garbage collection facility. The Daily garbage generation per house is $1.5 \mathrm{~kg}^{*}$ (The Tribune dec 2014) and the total garbage collection in Jalandhar is 500metric tons.

To manage the waste by keeping in view of its

$\checkmark$ Collection-Waste collection techniques and methods.

$\checkmark$ Routing-Transportation of waste from household level till the waste dump.

$\checkmark$ Disposal-Disposal of waste using landfill site or waste to manure plants.

As the calorific value of Indian waste is $800 \mathrm{kilo}$ cal $/ \mathrm{kg}$.It becomes $2600 \mathrm{kilo} \mathrm{cal} / \mathrm{kg}$ by let to get dry. In Indian incinerator is not environmentally feasible, as it produces canceric gases.

Keywords - Jalandhar, Municipal corporation, solid waste, health hazards, million liters discharge (M.L.D).

Assistant Professor, D.A.V University Jalandhar, Punjab, India

Assistant Professor, Sant Baba Bhag Singh University, Jalandhar, Punjab, India.

\section{INTRODUCTION}

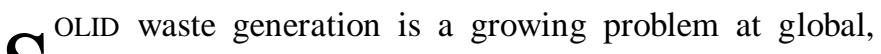
regional and local levels. Solid wastes are those waste materials produced by various activities of the society, which have lost their value to the first user. Improper disposal of solid wastes pollutes all the vital components of the living environment. Urban society rejects and generates solid material regularly due to rapid increase in production and consumption. Jalandhar is very famous trade and commerce centre of the state and has international specialization in manufacturing of Sports Goods, Leather Goods, Hand Tools, Pipe Fittings and Surgical Implements etc. Jalandhar provides varied type of tourism such as Religious and Historical Tourism, Medical Tourism, Educational Tourism, Recreational Tourism and Rural Tourism. The eminent tourist attraction points are Devi Talab Mandir, Tulsi Mandir, Shiv Mandir, and Pushpa Gujral Science City etc.

\subsection{Solid waste}

India is having rapid population growth and industrialization and in turn is not immune to the harmful effects of solid waste on its environment. The majority of human activities in one or another form result in the generation of waste. Solid waste management in Indian cities has become a major concern over a few years. A review of existing of literature reveals that number of studies on municipal solid waste has been undertaken. In India, municipal authorities are responsible for managing municipal solid waste and are often unable to perform their duties effectively because of lacking in-house capacity to handle the complexities of the process.

\subsection{Impacts}

The most deteriorating effect of waste mismanagement is on the Economy of a city, as the city grows the waste generation also increases which in turn increases the burden of waste management on the city infrastructure in terms of space and resources.

The next effect of mismanagement of waste occurs on the Environment. The aesthetics of the city changes in negative manner, and health of the residents which comes in direct contact of waste mismanagement area suffer the most. Leeching of harmful material into ground water causes serious health concerns and incurable disease. If the waste is not segregated nor disposed of properly in the city it may 
follow the footsteps of Italian city of Campania, which is now called the Toxic waste land of Italy.

\section{CONDITIONS WHICH RESULTS IN THE GROWTH OF WASTE IN INDIA}

\subsection{Rapid Growth of Indian Cities}

The growth rate of most of the Indian cities is very fast, due to rural to urban movement of peoples. Migration trends leads to increased densities, thus results in overburdening of infrastructure and creates unfavorable conditions of living.

\subsection{Urban Sprawl}

The unplanned extension of city limits results in the formation of clusters which generally don't have any basic facilities of water, sewerage system, and solid waste management. The basic service of waste picking and disposing are not followed in these areas and the local population also doesn't care to take necessary steps to segregate waste of their own.

\section{Solid WASte MANAGEMENT}

Municipal solid wastes generally include non-hazardous solid waste from the city, which need to be collected and transported frequently to a processing or a disposal sites. Solid waste encompasses of both heterogeneous materials and homogeneous materials. Municipal Solid Waste is composed of refuse and trash. There are various categories of municipal solid waste such as food waste, commercial waste, agricultural waste, institutional waste, industrial waste, constructional waste, rubbish, and street sweeping waste. Municipal solid waste consists of recyclable materials like paper, glass, plastic and metals; toxic substances like pesticide, paints, used medicines and batteries; compostable organic matter like fruits, vegetable and food waste.

\subsection{Need for Solid Waste Management}

Poor Conditions of Collection Containers and Areas around them

The condition of the open containers used during the primary collection and storage is very unhygienic. Foul smell, propagation of flies and other disease causing vectors are quite common at these sites.

TABLE I

COMPOSITION OF MUNICIPAL SOLID WASTE IN JALANDHAR

\begin{tabular}{|l|l|}
\hline Biodegradable & Non-biodegradable \\
\hline Food scraps & Non usable Sports products \\
\hline Worn out cloths & Plastic \\
\hline Ash & Rubber \\
\hline Vegetables & Bottles \\
\hline Charcoal & E-waste \\
\hline Wood & Tile debris \\
\hline
\end{tabular}

Smart Waste Management (Govt. of India, Smart Cities Guidelines)

The three main criteria for waste management are Collection, Transportation and Disposal

\subsubsection{Collection for Smart Management}

This is the stage at which maximum resource can be saved .The collection of waste must be in the segregated form which means the waste must be segregated at the source i.e. the household levels. The waste must packed in different bags which can be differentiated according to their color or according to their labels.

\subsubsection{Transportation of Waste for Smart Management}

This stage can act as the most time saving stage from. Collection trucks can be fitted with the G.P.S system which can enable them to choose the most convenient route to the disposal site during rush hours.

Trucks need to be provided with automatic tipping platform with different stacks which in turn help in reducing the time of manual filling of trucks .The waste lifting platforms should be provided in such a manner that manual labor requirements are minimum.

\subsubsection{Disposal of Waste in a Smart Way}

The disposal of waste is the last stage of solid waste management. It can be achieved by segregating waste at the source of the waste. If the waste is segregated at the source it can used most efficiently and easily.

\subsection{Need for Solid Waste Management in Jalandhar City}

With population of above 10 lakh Jalandhar is fast growing toward progress but this progress comes with a price, in the form of solid waste management, encroachments and urban transport problems. There are total 60 wards in Jalandhar which soon be increased to 63 with the delimitation of some wards. Total waste generated in the city is 500metric tones * per capita waste generation per house in Jalandhar is $1.5 \mathrm{~kg}$.

Being located in the center of Punjab it is the hub of medical and educational activities. There are total 1500 sweeper ${ }^{* *}$ employed which is highest in Punjab. (*-M.C data **-Performa for submitting solid waste information)

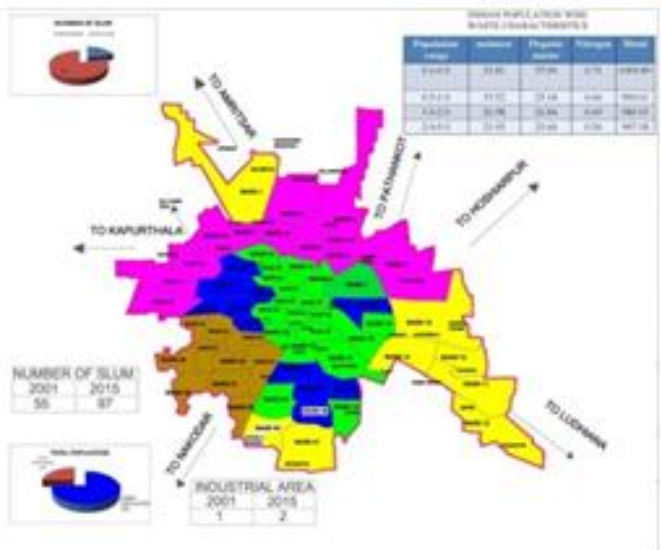

Fig 1: Area wise map Jalandhar city

\subsection{Land use and Waste Generation in Jalandhar City}

Maximum waste is generated by the residential area as it is the main constituent on the city population. Waste is not segregated at the household level or even at the ward level mixed waste is then transported to the dump site. 
TABLE II

PERCENTAGE OF WASTE GENERATED

\begin{tabular}{|c|c|c|}
\hline Sr.no. & Waste type & $\begin{array}{c}\text { Waste generated tone } \\
\text { per day }\end{array}$ \\
\hline 1 & Residential waste & 212 \\
\hline 2 & Commercial waste & 124 \\
\hline 3 & Institutional waste & 13 \\
\hline 4 & Hotel \& Resorts & 85 \\
\hline 5 & $\begin{array}{c}\text { Recreational \& } \\
\text { Landscaping waste }\end{array}$ \\
\hline 6 & Street sweeping & 65 \\
\hline & Total Waste & 500 \\
\hline
\end{tabular}

Source -Jalandhar M.C 2015

\subsection{Sweeping}

There are total $\mathbf{2 7 1 4}$ safai sewak including drivers of tipper truck, in total there are 1500 sweeper employed by municipal corporation Jalandhar, excluding the man power employed by the private company Jindal infratech limited. Sweeper in Jalandhar generally works 7 hours a days , 6 days a week. The assigned length of road given to each sweeper is $1 \mathrm{~km}$.There is no automatic machine in Jalandhar for sweeping roads.

TABLE III

QUALITY WISE SERVED AREA IN JALANDHAR

\begin{tabular}{|c|l|l|}
\hline Source & $\begin{array}{l}\text { Type of activities } \\
\text { and facilities }\end{array}$ & Type of M.S.W \\
\hline $\begin{array}{l}\text { Residential and } \\
\text { open spaces 90\% }\end{array}$ & $\begin{array}{l}\text { Single and multi } \\
\text { family, bus stand }\end{array}$ & $\begin{array}{l}\text { Paper, card board, } \\
\text { organic matter }\end{array}$ \\
\hline $\begin{array}{l}\text { Commercial and } \\
\text { street sweeping } \\
5 \%\end{array}$ & $\begin{array}{l}\text { Offices and } \\
\text { institution }\end{array}$ & $\begin{array}{l}\text { Paper, plastic, } \\
\text { inorganic, organic } \\
\text { waste }\end{array}$ \\
\hline Industrial 5\% & $\begin{array}{l}\text { Small and medium } \\
\text { industries }\end{array}$ & $\begin{array}{l}\text { Toxic, organic, } \\
\text { waste }\end{array}$ \\
\hline
\end{tabular}

\subsection{Collection}

The total collection of solid waste in Jalandhar is carried out by municipal corporation Jalandhar and jindal infra tech limited in collaboration. An estimated $90-95 \%$ of city area is covered by municipal and Jindal Infratech tippers. No segregation of waste is done at source or at the transfer station or either at the disposal site. Bins provided by M.C are generally of $1 \mathrm{~m}^{3}$ and $4.5 \mathrm{~m}^{3}$ and at some places the there is four walled space provided which act as an waste collection dump.

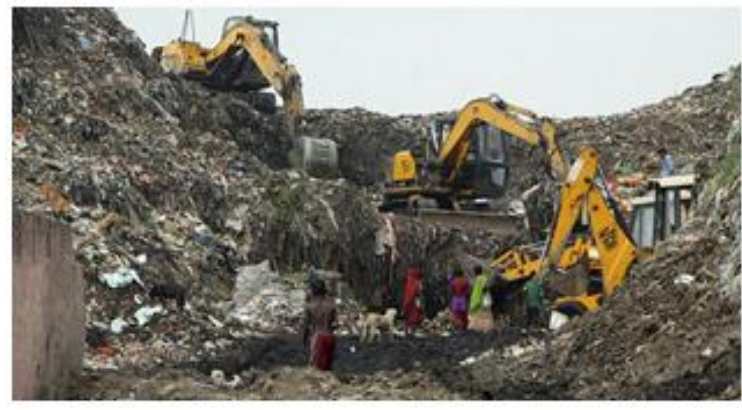

Fig 2: Wariana waste dump

\section{PROBlems}

\subsection{Turning Waste Into Sustainable Substance, A Distant Dream for Jalandhar}

\subsection{Proposed Site Mired in Controversy}

The civic authorities here have failed to break the deadlock with villagers of Jamsher Khas to set up a Municipal Solid Waste (MSW) plant in their area. Wariana dump is exhausted which makes the MC dumps waste in villages.

Due to lack of MSW processing facility here, the decadeold lone garbage dump spread over 14 acres in Wariana village has exhausted over a dozen times its capacity in the past 80 years causing a severe health hazard to around 2 lakh people living nearby.

As the dump could not accommodate further, JITF Urban Waste Management (Jalandhar) Ltd, the MSW Company for Jalandhar cluster, had begun to dump around 480 metric tons of daily garbage at secluded areas in the city's periphery and in the two ponds at Qadian and Jugral villages situated nearby. Though the Municipal Corporation of Jalandhar (MCJ) has proposed to construct a solid waste management plant at around 25 acres at Jamsher Khas village, people of nearby villages have opposed the plan.

\section{V.PROPOSALS FOR JALANDHAR CITY}

\subsection{New Waste Disposal Site}

A new waste disposal site is proposed at Jamsher village which is present of the Jalandhar -Nakodar road and is outside the present municipal and local planning area boundary of the city. As the site is proposed to be 25 acre it can be made as an engineered landfill site just as in the case of Ahmadabad city.

\subsection{ZERO WASTE Ahmadabad-A national Model}

\subsubsection{AMC-Solid Waste Management Practices}

- Daily collection of 4000 metric tones (More than 600 Grams per head per day)

- More than 12,500 Street sweepers-1484 km road area swept on a daily basis.

- $100 \%$ coverage in street sweeping on a daily basis

- Collection from all residential and commercial units under Door / Gate to Dump project, more than 600 vehicles are deployed and daily 1600 metric tons of waste is collected in this manner.

- Identified more than 850 locations as waste collection points where 1050 closed body 7 cubic meter M.S. Community storage bins have been provided. AMC ensures that these containers are lifted at least once in a day and daily 1100 metric tons of waste is collected in this manner.

\subsubsection{Scientific Disposal of Construction \& Demolition Waste}

DNP Infrastructure Pvt. Ltd has been awarded the project for Design, Construct, Operate \& Maintain a daily 300 tons processing plant for Construction \& Demolition waste and 
collection \& transportation of such waste from city area on Public Private Partnership mode for 30 years. AMC has allotted 5 acres of land for processing plant. It will be operational in October, 2016 and going to make Bricks, Tiles $\&$ other materials from such waste.

\subsection{New Transfer Station Site}

Two new secondary disposal sites are proposed one at

- Ravidass chownk on Jalandhar -Nakodar road and the other at ,

- Ram a Mandi flyover on Jalandhar -Hoshiarpur road.

As now there is only one secondary site which is present at the Burtlon park area the waste from throughout the city reaches the Burtlon park, which causes lot of inconivence and environmental impact as the waste is dumped at Burtlon park which is located at the center of the city

\section{REFERENCES}

[1] Akolkar, A.B. (2005). "Status of Solid Waste Management in India, Implementation Status of Municipal Solid Wastes, Management and Handling Rules 2000", Central Pollution Control Board, New Delhi.

[2] CPHEEO, Ministry of Urban Development, Govt. of India (2005),Report of the Technology Advisory Group on Solid Waste Management .

[3] Gupta S.K., (2003) "Municipal Solid Waste - A Complete Synopsis" Indian Institute Of Technology, Bombay

[4] Journal on integration rag pickers in Pune.

[5] Kumar, S. and Gaikwad, S.A., "Municipal Solid Waste Management in Indian Urban Centres: An Approach for Betterment", Urban Development Debates in the New Millennium.

[6] Kurian Joseph (2002), "Perspectives of solid waste management in India."

[7] Luis F. Dias \& others ( 1996) (ISWA, Copenhagen) Solid Waste Management for Economically Developing Country.

[8] Mahadevia Darshini, Pathak Manish ( 2005), "Local Government Led Solid Waste Management in a Small Town - Suryapet".

[9] Master plan Jalandhar 2011.

[10] NEERI, (1994). "Solid Waste Management in Greater Bombay".

[11] Sahu Amiya Kumar. (2007) "Present Scenario of Municipal Solid Waste (MSW) Dumping Grounds in India"

[12] Sunil Kumar, J.K. Bhattacharyya , A.N. Vaidya, Tapan Chakrabarti, Sukumar Devotta, A.B. Akolkar (2009,) "Assessment of the status of municipal solid

[13] Waste management in Metro Cities, State Capitals, Class I Cities, and Class II towns in India: An insight." 